\title{
Bringing the French Empire (to the) Home?
}

\author{
Hugh McDonnell \\ Department of European Languages and Cultures, University of Groningen \\ h.m.mcdonnell@rug.nl
}

Véronique Dimier, The Invention of a European Aid Bureaucracy: Recycling Empire (Basingstoke: Palgrave Macmillan, 2014), 240 pp. (hb), ISBN 9780230300002.

Ed Naylor, ed., France's Modernising Mission: Citizenship, Welfare and the Ends of Empire (Basingstoke: Palgrave Macmillan, 2018), 258 pp. (hb), ISBN 978-1-1-137-55133-7.

Amelia H. Lyons, The Civilizing Mission in the Metropole: Algerian Families and the French Welfare State during Decolonization (Stanford: Stanford University Press, 2013), 324 pp. (hb), ISBN 9780804784214.

Minayo Nasiali, Native to the Republic: Empire, Social Citizenship, and Everyday Life in Marseille since 1945 (Ithaca: Cornell University Press, 2016), 231 pp. (hb), ISBN 9781501704772.

Félix F. Germain, Decolonizing the Republic: African and Caribbean Migrants in Postwar Paris, 19461974 (East Lansing: Michigan State University Press, 2016), 232 pp. (pb), ISBN 978-1-61186-204-1.

In November 2018 eight people, including a mother from the Comoros and residents from Tunisia and Algeria, died when two buildings collapsed in the run down area of Noailles in the old port area of Marseille. A 2015 government report had already warned that 40,000 dilapidated and dangerous homes put 100,000 people at risk in France's second city, but campaigners say little was done. The tragedy occasioned widespread anger about run down and exploitative housing in the Mediterranean city. ${ }^{1}$ It also refocused public attention on housing and the concept of the home. In turn this raised questions about how housing and the home connect to space and social justice, the division of labour between national and local government, citizenship and 'the right to the city'.

Recent scholarship on housing in post-war France suggests that these kinds of questions are nothing new either in Marseille or in France as a whole. The form and responses to such questions have certainly varied in the post-war period. Nonetheless, recurring themes have arisen in thinking about housing: evolving norms of domesticity; the range, logics and limitations of French state power in its various manifestations; the relation between technocratic and bureaucratic administration, on the one hand, and clientelism and personalised relations, on the other; and stratified access to housing, often according to criteria of 'Frenchness'. Strikingly, this Frenchness was often of a particular kind, which was consistently elided with being or becoming modern and European. Discourses of 'Europe', then,

\footnotetext{
1 Angelique Chrisafis, 'Marseille Falls Apart: Why is France's Second City Crumbling', The Guardian, 21 Mar. 2019. https:// www.theguardian.com/cities/2019/mar/21/marseille-falls-apart-why-is-frances-second-city-crumbling

2 For a non-French take on equivalent questions, see Pedro Ramos Pinto, 'Housing and Citizenship: Building Social Rights in Twentieth Century Portugal', Contemporary European History, 18, 2 (2009), 199-215. For a recent engagement with and critique of Henri Lefebvre's urban studies, from which derive the concept of the 'right to the city', see Andrew Newman, Landscape of Discontent: Urban Sustainability in Immigrant Paris (Minneapolis: University of Minnesota Press, 2015).

(C) The Author(s), 2020. Published by Cambridge University Press. This is an Open Access article, distributed under the terms of the Creative Commons Attribution licence (http://creativecommons.org/licenses/by/4.0/), which permits unrestricted re-use, distribution, and reproduction in any medium, provided the original work is properly cited.
} 
did not only inform French government officials and diplomats in Paris or Brussels. Both state and non-state actors' perceptions of Europeanness and, indeed, non-Europeanness also determined access to housing and citizenship throughout the post-war French republic.

The polyvalence of the notion of home makes it an intriguing and fecund concept for scholars. Aside from an abode, where the public and the private, affect and function, converge, it also signifies a point of origin or centre. It is in this sense that some scholars have used the phrase 'bringing the empire home. ${ }^{3}$ The ambiguity surrounding the notion of 'home' is approached in an unusual and productive way by Véronique Dimier in her 2014 work on returning French colonial administrators and their role in the European development bureaucracy, entitled The Invention of a European Development Aid Bureaucracy: Recycling Empire.

Dimier examines how a relatively small group of French colonial administrators shaped European Economic Community (EEC) development policies and practices in the broader context of the advent of European political institutions. A political scientist by background, she looks at the nascent Directorate General for Development and Cooperation (DG8) of the European Commission through the lens of neo-institutionalist theory. Nonetheless she has much to say that is of interest to historians of Europe. Her point of entry is the Corsican ex-colonial administrator Jacques Ferrandi, his leadership of the European Development Fund (EDF) in Brussels from 1963 and the ways his team 'recycled' colonial practices. Dimier's argument differs from that of Peo Hansen and Stefan Jonsson, for whom the EEC and European Union (EU) were from the outset designed to enable a rational, co-European colonial management of the African continent. ${ }^{4}$ The recycling of colonialism in her account refers instead to an institutional identity that was shaped by the inheritance of certain French colonial ways of doing politics, transferred to a new institutional home in Brussels: 'mutual trust and obligations, personal and affective ties, opaque and anti-bureaucratic methods linked to the discretionary power of leaders, permanent exception to the rule and compromise. ${ }^{5}$ Dimier argues that this esprit de corps in large part shaped the EEC's development approach. Crucially, it continued to do so despite personnel and conceptual changes within the DG8, as well as the entry of new member states (notably the United Kingdom) and associated developing countries from the 1970s onward. This emergence of a neo-patrimonial system of authority within the DG8 in many ways paralleled and duplicated Jacques Foccart's better known clientelist Françafrique network (the two men in fact never met). ${ }^{6}$

Successfully fending off internal opposition from bureaucratic reformers, Ferrandi and his circle of former colonial administrators were convinced of the need to adapt to on the ground African realities in making decisions about development projects, rather than appealing to abstract scientific reasoning. Against contemporary insistences on the new direction of development policy, Dimier emphasises its continuities. She draws a line connecting Ferrandi's ideas back to the famous director of the Ecole

\footnotetext{
3 See, for instance, Catherine Hall \& Sonya O. Rose, eds., At Home with the Empire: Metropolitan Culture and the Imperial World (Cambridge: Cambridge University Press, 2006); Herman Lebovics, Bringing the Empire Back Home: France in the Global Age (Durham, NC.: Duke University Press, 2004) and Zine Magubane, Bringing the Empire Home: Race, Class and Gender in Britain and Colonial South Africa (Chicago: University of Illinois Press, 2004). On the polyvalence of the notion of 'home', see also Shannon L. Fogg, Stealing Home: Looting, Restitution and Reconstructing Jewish Lives in France, 19421947 (Oxford: Oxford University Press, 2017).

4 Peo Hansen and Stefan Jonsson, Eurafrica: The Untold History of European Integration and Colonialism (London: Bloomsbury Academic, 2014). On Europe's post-colonial relationship with the Third World, see also Giuliano Garavini, After Empires: European Integration, Decolonization and the Challenge from the Global South 1957-1986, trans. Richard R. Nybakken (Oxford: Oxford University Press, 2012).

5 Véronique Dimier, The Invention of a European Aid Bureaucracy: Recycling Empire (Basingstoke: Palgrave Macmillan, 2014), 2.

6 Ibid., 68. On Foccart, see Jean-Pierre Bat, Olivier Forcade and Sylvain Mary, eds., Jacques Foccart: archives ouvertes (19581974) (Paris: PUPS, 2017); Pierre Péan, L’Homme de l'ombre: éléments d'enquête autour de Jacques Foccart, l'homme le plus mystérieux et le plus puissant de la Ve république (Paris: Fayard, 1990) and Frédéric Turpin, Jacques Foccart: dans l'ombre du pouvoir (Paris: CNRS Editions, 2015).
} 
colonial between 1937 and 1946, Robert Delavignette. Conversely, she traces the thought of both Delavignette and Ferrandi in the work of Edgar Pisani, the French Commissioner for Development from 1981. Dimier points to a certain republican left idealisation of African societies whose backbone were small villages, where 'black peasants' lived in harmony with one another and nature, bound together by religious solidarity, collective working and, in Delavignette's phrase, 'communion with the land'. This vision of African societies was influenced by these administrators' own similarly romanticised view of the French rural past and provincial cultures. It also reflected a conception of society characteristic of the French urban elite from the beginning of the twentieth century that held that man and land were joined and were part of the same living organism. Man's social existence, culture and 'soul' depended on remaining 'rooted' in his native land ('terroir"). Hence rural exodus, urbanisation and industrial growth were considered a threat to social cohesion and political order in both France and the colonies.

A key virtue of Dimier's work is its broadened understanding of colonial practices. In her account they are both more banal and more tenacious than the direct imposition of power. Similarly, the dull bureaucratic logics of the DG8 indicated not straightforward coercion but rather asymmetries of power between the EEC and European states on the one hand, and African clients on the other. The maintenance of colonial styles of working had less to do with foresight or calculation in the service of vested interests than the inheritance of operational repertoires. Dimier makes the case for their perpetuation beyond the era of decolonisation by deftly holding in a single frame of analysis the continuity of discourse, ideas and practices alongside emerging moments of their contestation. From the point of view of historians, her case would be stronger still with more reflection on the heavy dependence on interviews as sources, and certainly greater consideration of the views of the EDF's African interlocutors. Nonetheless, Dimier's is an important achievement, not least since it circumvents interpretations that cling either to an overly simplified account of the recycling and reconstitution of colonialism on the one hand, and a European boosterism on the other, which subscribes to the EEC foundation myth as a post-colonial project.

Another work that straddles the metropole-colonies divide is the 2018 collection France's Modernising Mission: Citizenship, Welfare and the Ends of Empire, edited by Ed Naylor. The book's impressive range neglects only French Indochina geographically, and perhaps gender and labour thematically. The first of the collection's three sections encompasses chapters by Tony Chafer on battles over France's policy of adapted education in French West Africa; by Liz Fink on representative democracy and the institution of the chieftaincy, also in French West Africa; and by Benoit Trépied on the long-running question of the meaning of decolonisation in New Caledonia. Section two examines 'Mental Maps and the Territory' and includes chapters by James McDougall on Robert Montagne and the rule of experts in late colonial French Africa, Neil MacMaster on the French colonial state and its social engineering of rural space, 1843-1962 and Jim House on shantytowns and rehousing in late colonial Algiers and Casablanca. The third and final section then turns to metropolitan legacies. Naylor's chapter examines the Marseille-based welfare charity Aid to Overseas Workers (Aide Aux Travailleurs D'Outre Mer; ATOM) across the threshold of decolonisation between 1950 and 1975 . Françoise de Barros's chapter investigates local residents' protests against shantytowns in the Paris area in the 1950s and 1960s. And, finally, Abdellali Hajjat assesses colonial legacies, housing policy and riot prevention strategies in the Minguettes district of Vénissieux on the outskirts of Lyon.

These various contributions show how modernisation involved reinventing the terms that bound colonised or formerly colonised peoples to the metropole, but also how the French state struggled to control these dynamics. The collection is particularly useful in posing questions about the nature of the French government apparatus and its scales, logics and limits. Strikingly, housing and the home were core targets of state attempts at social engineering.

7 For a recent fascinating examination of the conception of terroir, see Andrew W. M. Smith, Terror and Terroir: The Winegrowers of the Languedoc and Modern France (Manchester: Manchester University Press, 2018). 
If the independence of Algeria in 1962 is often seen as a fundamental threshold, much recent scholarship nonetheless points to continuities in discourse and policy after decolonisation without suggesting that 'bringing the empire home' can be understood as a simple transmission of colonialism to the metropole. This point is convincingly made in Naylor's chapter on ATOM, whose work included helping beneficiaries with housing problems. ATOM's directors, Louis and Simone Belpeer, in many ways typified the French colonial project in their personal views and in their organisational capacity. In line with a long-standing tradition of the French state delegating social services to civil society actors, ATOM was employed as a kind of autonomous auxiliary organisation. During the Algerian War this took on particular importance in the context of the hearts and minds campaign, as part of which welfare provision to Algerians was bound up with security objectives. ${ }^{8}$ The discrepancy that Naylor locates between ATOM's discourse and practice was symptomatic of the Belpeers' ambiguous relationship to the French empire. More than that: 'ATOM's case is suggestive of the variety of forms that the "modernising mission" could take and the plurality of French "colonial minds"'.9

The Belpeers subscribed to the idea of a discrepancy between Europeans and North Africans, seeing the latter as particularly prone to inadaptation in the West. In effect, they already considered the latter as immigrants despite the fact that before the end of the Algerian war they were nominally French. This view was buttressed by the common supposition that the bidonvilles that housed most of the Algerians with whom they dealt embodied and confirmed this incapacity, even though no more than a fraction of North Africans ever inhabited them. In her chapter, Françoise de Barros likewise shows how neighbours of the shantytowns in the Paris suburbs of Nanterre and Champigny made complaints positing a natural and hermetic frontier distancing them from the uncivilised essence of these slums. Importantly, though, the example of ATOM and the Belpeers manifests how binary categorisations, of which European and non-European was one of the most ubiquitous, were continually undermined by experiences that could not be contained within that framework. ${ }^{10}$

A further unifying theme running through the book is the question of 'the colonial'. In his chapter, Abdellali Hajjat usefully suggests that the very concept is subject to symbolic struggles. He argues that symbolic resources and practices constructed in the colonial context can extend beyond that domain spatially and temporally and can be 'reactivated' in the metropole. This does not at all imply an identical reproduction but instead something more like a reconfiguration in new historical contexts and under new judicial constraints. ${ }^{11}$ To illustrate he examines the prevalence of the discourse of the 'tolerance threshold' (seuil de tolerance) in regard to the Minguettes neighbourhood in Vénissieux on the outskirts of Lyon between the end of the 1960s and the beginning of the 1980s. For Hajjat the 'seuil de tolérance' was a corollary of the colonial theory of assimilation, particularly its variant which blurred the goal of Europeanising immigrants with pessimism about their capacity to be Europeanised, presupposing their propensity to foment conflict by their mere presence. In practical terms this translated into limiting the percentage of non-Europeans living in the housing estates of Minguettes, even if this meant allowing housing units to stand empty.

The same rationale of the tolerance threshold informed the police's strategy in the aftermath of the 'hot summer' disturbances in 1981. The problem of delinquency in the estates was reduced to a conflict between French and foreigners 'of the European race' on one side and French and 'exogenous' foreigners (i.e. blacks and Arabs) on the other. Doubts about the capacity of minorities to assimilate to the 'European' majority were compounded by the view that they were even less capable of doing so in proportion to their size relative to the majority. Thus the view of minorities as unassimilable was

\footnotetext{
${ }^{8}$ On the interweaving of security and welfare, see also Jim House and Neil MacMaster, Paris 1961: Algerians, State Terror, and Memory (Oxford: Oxford University Press, 2006).

9 Ed Naylor, 'Promoting "Harmonious Cohabitation" in the Metropole: The Welfare Charity Aide Aux Travailleurs D’Outre Mer (1950-1975)', Ed Naylor, ed., France's Modernising Mission: Citizenship, Welfare and the Ends of Empire (Basingstoke: Palgrave Macmillan, 2018), 189.

10 Ibid., 184.

11 Abdellali Hajjat, 'Colonial Legacies: Housing Policy and Riot Prevention Strategies in the Minguettes District of Vénissieux', in Naylor, France’s Modernising Mission, 226-7.
} 
exponentially fostered by the flight of more prosperous residents - a curious essentialist positing of characteristics that at the same time were also held to depend to a very large extent on contingent social developments.

Amelia Lyons deals with similar issues of the recalibration of imperial administration in the post-Second World War world in The Civilizing Mission in the Metropole: Algerian Families and the French Welfare State during Decolonization. Lyons argues that what she terms the 'Algerian welfare network', encompassing the state and civil society partners, reinvented the colonial civilising mission by fusing it with the post- 1945 welfare state to give rise to a 'modernising mission in the metropole. ${ }^{12}$ State policy on housing and the home in the metropole surpassed antecedent colonial administration in that the domestic realm now 'offered the promise of total transformation; for the administrators and social workers of the Algerian welfare network, its programs promised the kind of access to the household the colonizer had dreamed of but never attained'. ${ }^{13}$

Experts insisted that housing 'represented the "determinant factor" in Algerians' "integration" into "modern life". ${ }^{14}$ What is more, 'the state attached great political importance to transforming Algerian migrants and to making them feel "almost at home"'. ${ }^{15}$ This 'almost' is telling. As Lyons puts it, 'by qualifying Algerians' place in the metropole, these experts exposed their lingering concerns about the risks Algerian settlement posed to the nation's "vitality". Experts, advocates and bureaucrats all agreed that the ultimate goal was for Algerian families to 'evolve' sufficiently to live side by side with metropolitan families. ${ }^{16}$ Support for Algerian housing coexisted with widespread discrimination, however. Caught between simultaneous dynamics of inclusion and exclusion, French universalist commitments were difficult to square with 'lingering eugenic fears that Algerians' perceived racial and cultural differences could constitute an insurmountable impediment to their integration'. ${ }^{17}$

While it is a shame that one does not hear more about the reactions of Algerians themselves to the state's attempts to manage them, Lyons' focus on the Algerian welfare network is particularly useful as an exposition of the configurations and contradictions of French state power. Her work gives a greater sense of the inadequacy of notions of 'bringing the empire home' since 'the welfare network was never wholly metropolitan or colonial but rather grew out of techniques, institutions and personnel that moved fluidly across the Mediterranean Sea'. ${ }^{18}$ Furthermore, she skilfully delineates the interconnections of state institutions, the state-subsidised non-profit housing organisation the National Society for the Construction of Workers' Lodgings (Société national de construction de lodgements pour les travailleurs; SONACOTRAL) and private charitable associations, as well as highlighting the conflicting priorities of different government ministries (primarily the Ministries of Labour, the Interior and Public Health and Population). The book likewise stresses the extension in the 1950s of the professionalisation of state planning. This drew on a nexus of knowledge and power encompassing social science and 'institutional architects', who worked to modernise the nation and its people by promoting 'social evolution'. ${ }^{19}$ Lyons explains, furthermore, how the Algerian welfare network drew on an array of traditions encompassing the Third Republic, Vichy and imperialism. These included social Catholicism, social scientific expertise on population management, racism and eugenics, including fears of miscegenation.

\footnotetext{
12 Amelia H. Lyons, The Civilizing Mission in the Metropole: Algerian Families and the French Welfare State during Decolonization (Stanford: Stanford University Press, 2013), 1.

13 Ibid., 5 .

14 Ibid., 116. For a work which examines expertise in the formulation of housing policy and in the construction of knowledge of built urban environments, see Kenny Cupers, The Social Project: Housing Postwar France (Minneapolis: University of Minnesota Press, 2014).

15 Lyons, The Civilizing Mission in the Metropole, 4.

16 Ibid., 131.

17 Ibid., 18.

18 Ibid., 3.

19 Ibid., 60.
} 
Lyons' anatomy of power provides fascinating empirical fodder for theoretical questions of the calibration of agency and structure within institutions integral or auxiliary to the French state. One of the most interesting features of her work is her attention to the dilemmas faced by many functionaries, service providers and social workers. These found their often genuine, albeit typically paternalistic, commitment to the social uplift of Algerians thwarted by the demands of monitoring and surveillance. By no means devoid of autonomy or critical distance, they nevertheless found themselves constrained by a state machinery that targeted Algerians. These personnel resisted complicity with the coercion of, and certainly the overt state violence against, the Algerians they served. Nonetheless, they commonly shared a binary conceptualisation of Algerians as moulded by an Oriental, patriarchal, pre-modern society, and as victims of atavistic Algerian nationalism. To counter the latter and to make a new home in France, Algerians needed to 'evolve' according to the interchangeable imperatives of Europeanisation, Westernisation and modernisation. Such evolutionary schemata, furthermore, provided a useful ideological circularity: Algerians denied housing were deemed undeserving of that housing by dint of their exclusion.

However, despite her own nuanced portrait of the welfare network, Lyons perhaps occasionally overstates the zeal of French officials. For instance, she compares the righteousness of nineteenthcentury French colonialists on bringing French civilisation to backward subjects in Algeria with post-Second World War 'administrators and personnel of the burgeoning welfare network herald [ing] their commitment to bringing Algerian migrants the benefits of modern, Western culture.. ${ }^{20}$ Certainly, Lyons shows that this was so in many cases. But her emphasis on the importance of latent repertoires of knowledge and power does not necessarily imply such strong belief on the part of state functionaries or social workers.

One of the most significant and novel contributions of Lyons's work is her focus on gender and family as categories in French administration of the housing of Algerians. ${ }^{21}$ A key development was in 1950 when many experts began calling for Algerian family settlement. As 'anchors of settlement', women and children could depoliticise male workers and prevent racial miscegenation. Seemingly indifferent to shifting conceptions of gender already in the post-war period, this approach promoted a conventional, patriarchal model of the European family. ${ }^{22}$ In keeping with the shift of concern from Algerian unemployment to Algerian nationalism, the domestic environment created by family settlement promised a means to manipulate their 'collective mentality' in order to generate loyalty to France and to ditch their 'irrational hostility toward European civilisation'. Similarly, women housed in transitional housing (cités de transit) were judged on their success in 'adapting to European customs' to see if their families were suitable for transfer into one of the new high-rise subsidised housing projects (Habitation à loyer moderé; HLM). This raises the question of the extent to which Algerians (and indeed other immigrants) were required to believe in their Europeanisation and modernisation in acquiring French domestic culture or were just to be seen to conform to it outwardly. There is evidence for each interpretation, which correlates with the complex and uneven nature of the welfare network. ${ }^{23}$

20 Ibid., 17.

21 Another work with much to say about housing and gender roles, albeit with less emphasis on their colonial dimensions, is Nicole Rudolph, At Home in Postwar France: Modern Mass Housing and the Right to Comfort (New York: Berghahn, 2015).

22 On shifting understandings of family and gender in the post-war period, see Sarah Fishman, From Vichy to the Sexual Revolution: Gender and Family Life in Postwar France (New York: Oxford University Press, 2017) and Herrick Chapman, France's Long Reconstruction: In Search of the Modern Republic (London \& Cambridge, MA: Harvard University Press, 2018), particularly chapter 4: 'Family Matters: Expertise, Gender, and Voice in the Social Security State', 109-63.

23 Amit Prakash argues that policy aimed at educating immigrants on cultural forms and behaviour separated thought and action, so that only conformity was asked for, not belief. See Amit Prakash, 'Empire on the Seine: Surveillance, Citizenship, and North African Migrants in Paris (1925-1975)', PhD dissertation, Columbia University, $2008,280$. Conversely, Neil MacMaster argues that French social workers often 'suspected that conformity to official regulation and norms was a skilful ploy, an instrumental enactment of "correct" behaviour to gain strictly pragmatic and material goals'. See Neil MacMaster, 'Shantytown Republics: Algerian Migrants and the Culture of Space in the Bidonvilles', in 
It is noteworthy that state officials recognised that Algerian men's adoption of 'European customs' did not preclude them from being 'strongly anti-French Algerian nationalists'. But then discourse of Europeanisation could refer not simply to inculcation of French and European culture and customs but also the extension of control over non-European immigrants, or at least the reduction of any militancy on their part. More generally, though, Lyons's treatment of gender and family further highlights the multiple meanings and functions of administrative concepts and serves as a caution against attributing singular aims and logics to the French state.

Housing assumed greater importance during the Algerian War as part of a drive to secure the loyalty of Algerians to France and to break the organisation of the Algerian National Liberation Front (Front de libération nationale; FLN) in the metropole. The dormitories constructed for a flexible migrant labour force both segregated and facilitated surveillance of Algerian men. Lyons examines the 1959 decision to 'liquidate' these shantytowns, which required massive investment in family housing between 1959 and 1962. While worker housing construction continued, family housing provided a more visible demonstration of the state's commitment to help Algerians and its effort to shape and monitor Algerians' behaviour. Yet, comparatively few Algerian families moved into HLMs despite the rapid growth in construction. Instead metropolitans and 'returning' European settler 'black feet' (pieds noirs) moved into apartments reserved for Algerians. French officialdom's drive to incorporate Algerians into the French nation through housing provision was undermined by the conflicting conviction that others had a greater right to a home in France, in both the sense of right to a material abode and a claim to belonging. If the complex nature of the Algerian welfare network afforded it suppleness via its on the ground contact and knowledge, it also engendered contradictions so that the state impetus to tie Algerians to the republic could be thwarted by, for instance, local municipalities that did not approve of their mixing with the local population. Hajjat's example of the communist mayor of Vénissieux, Marcel Houël, is germane here. In 1982 Houël admitted his participation in the exclusion of non-Europeans taking up housing units, underpinned by his endorsement of the ideas of the 'tolerance threshold' and 'double racism', assigning the excluded responsibility for their own exclusion.

Minayo Nasiali's Native to the Republic complements Lyons's work and expands the timespan from the immediate post-1945 moment through to the new millennium. Her examination of modernisation, the modern French welfare state and social citizenship focuses on housing crises in Marseille in this period, and state and local responses to them. ${ }^{24}$ In so doing, Nasiali elucidates how 'the local is never solely local', capturing both the specificities of Marseille and how it also reflected national discourses and policies. ${ }^{25}$ Similarly, this was not a locality to which the empire was brought home. Instead, 'Marseille's position as a port city suggests a new way of thinking about the space of the imperial nation-state. Rather than a linear site of transmission, Marseille is a hybrid, mediated place where people from all over the empire were part of the post-World War II project to better manage and modernize the populace. ${ }^{26}$

Each chapter deals with an aspect of housing and the city's underclasses: slum clearances, family relocation, squatters' rights (or lack thereof), modernisation initiatives, 'reduced norm' housing and, of course, low-cost housing projects like the HLMs. Nasiali's approach emphasises the role played by ordinary people in shaping state and institutional responses to issues of housing. She argues that their everyday practices and common sense (in Paul Gilroy's sense of 'taken-for-grantedness') played an underestimated role in determining who deserved a home and, indeed, what kind of home.

Hafid Gafaïti, Patricia M.E. Lorcin and David G. Troyansky, eds., Transnational Spaces and Identities in the Francophone World (Lincoln, Nebraska: University of Nebraska Press, 2009), 88. One is also reminded here of the work of Gérard Noiriel, who points to the integrative power of the French state and immigrants' gradual acceptance of its values.

24 For a general history of Marseille, see Alèssi Dell'Umbria, Histoire universelle de Marseille: De l'an mil à l'an deux mille (Marseille: Agone, 2006).

25 Minayo Nasiali, Native to the Republic: Empire, Social Citizenship, and Everyday Life in Marseille since 1945 (Ithaca: Cornell University Press, 2016), 8.

26 Ibid., 9. 
Everyday life determined how space was configured and policed (in the sense of establishing and maintaining differentiation). The post-war Marseille home was far more than the sum of its bricks and mortar - or of its flimsier, deliberately temporary, materials, as was often the case for migrant housing in the city. It was permeated with ideas and expectations about republican citizenship and attendant competing claims to comfort, wellbeing and welfare. What might have seemed and been understood as banal and pragmatic neighbourhood management was in fact very often inextricably linked to ideological conceptions of belonging.

Nasiali's emphasis on 'everyday life' is in some ways misleading. Hers is not a study of Marseille inhabitants' quotidian routines of work and leisure. In another way, though, the restricted use of the concept is astute and revelatory. Housing policy, she argues, cannot be understood simply as the transmission of abstract and remote decisions of governmental departments. Rather, policy was mediated, refracted and shaped by its application on the ground, at the lived, even sensorial, level, in accordance with shifting notions of social citizenship. These notions were in turn moulded against the backdrop of contested visions of modernisation shaped by decolonisation and France's changing economic fortunes.

This involved shifting assumptions about difference, which informed how residents from diverse backgrounds imagined who was 'from' their neighbourhood and who therefore deserved the right to modern living. ${ }^{27}$ Residents' understandings of modernisation were formed both by the physical spaces of their 'little village' (petit village) and by perceptions about who belonged there. ${ }^{28}$ Likewise, when it came to determining where to house immigrants, local 'technicians' (techniciens), or technocratic experts, including urban planners, seemed to make decisions in terms of common sense and subjective perceptions of racial difference. ${ }^{29}$ This is not simply to point to the autonomy of local politics, although that was an important factor in Marseille housing, particularly in clientelist municipal practices. ${ }^{30}$ More precisely, this was about what can be thought of as the local articulation of national policies. Through innocuous quotidian interactions on the ground, subtle but significant discrepancies emerged between centralised state logics and their implementation. The post-war modernisation drive might have been distinctly top-down, but it was in large part at the local level that housing came to be seen as an essential right of citizens. And in housing campaigns and participation in housing planning and management, the very category of citizen was shaped at the local level in terms of who belonged and who did not. This commonly revolved around local understandings of who was productive and contributed to the construction of the space of the 'petit village'.

A key part of the local level story in Marseille was the diminishing confidence in modernisation with the end of the post-war economic boom and the onset of imperial hangovers. Nasiali's case studies suggest that, in the immediate post-war period, modernisation was largely considered an unqualified good. Indeed, moving to a modern home became a mark of social mobility and an important indication that the welfare state was working. ${ }^{31}$ However, as decolonisation and the end of the 'glorious thirty' (trente glorieuses) hit home, so too did confidence in modernisation recede. The promises of modernisation, especially in regard to the comfort and security of the modern home, were belied by perceptions of the onset of urban blight and alienation, housing estates scarred by unemployment and increased insecurity and the rise of the supposed 'immigrant problem'. ${ }^{32}$ By this point in the

\footnotetext{
27 Ibid., 42.

28 Ibid., 57.

29 Ibid., 77.

30 See also Melissa Byrnes's research, which demonstrates how policies towards bidonvilles differed markedly between nearby suburbs according to the politics of their respective municipal authorities. See Melissa Byrnes, 'Liberating the Land or Absorbing a Community: Managing North African Migration and the Bidonvilles in Paris's Banlieues', French Politics, Culture and Society, 31, 3 (2013), 1-20. On the relationship between local political actors and post-colonial minorities, see also Emile Chabal, 'Managing the Postcolony: Minority Politics in Montpellier, c. 1960-c. 2010', Contemporary European History, 23, 2 (2014), 237-58.

31 Nasiali, Native to the Republic, 5.

32 Ibid., 84.
} 
mid-1970s a new generation of sociologists and urban planners considered these issues in fresh ways. For these experts, the 'migrant housing problem' was a misplaced diagnosis of the failure of the post-Second World War modernisation project and of hubristic state efforts to manage everyday life. ${ }^{33}$ Instead they proposed greater resident participation in the management of their own spaces. They were disappointed, however, in instances when residents used such participatory schemes to reinforce exclusionary housing policies, limiting the number of 'extra-European families'. ${ }^{34}$

Nasiali's focus on the local level also shows how the binary opposition between Europeans and non-Europeans was often disrupted, as in the case of the Tilleuls housing project, many of whose residents were harkis (Algerians who had fought with the French during the Algerian war). ${ }^{35}$ As new families moved into the cité, many of the original families believed their neighbourhood was falling into decline. Among themselves, their ethnic and regional differences often counted for more than their shared harki past, sometimes to the extent of fuelling conflict. But together they affirmed their harki identity in the face of incoming Algerians, Tunisians, Senegalese and Comorians. As in other neighbourhoods, many in Tilleuls believed that their neighbourhood would benefit from a social 'rebalancing' (reéquilibration), and understood that this depended on having more 'native French' (français de souche) or 'European' families move into the cité. In this way, the harki residents were at one with local officials who also advocated encouraging more 'European' families to move into the neighbourhood. Nasiali writes that 'these discussions also underscore how diverse residents including former colonial subjects - helped to produce categories of race and ethnicity'. ${ }^{36}$ Or, one might add, how categories of race and ethnicity faltered in neatly distinguishing between insiders and outsiders as a means of rationalising differential entitlement and access to social citizenship.

One of Native to the Republic's most important contributions to an expanded understanding of post-war French social citizenship is its emphasis on the importance of space and how it was perceived, lived and demarcated at the local level. Particularly important was the relegation of certain urban areas often held to be in Marseille but not really of it. This could take the form of physical inscription of degrees of social citizenship that could only be perceived in proximity. Such was the case with the visibility of temporary building materials used for immigrant housing as opposed to, for instance, the use of building materials that 'emphasized permanence: integrating the European rapatriés into the national fabric. . . to ensure their long-term status as French citizens'. ${ }^{37}$ Furthermore, slums, transit cities or areas like the 'northern neighbourhoods' (quartiers nords) were often disdained as irredeemably out of place with the city to a greater degree than the sum of its immoral, dirty or foreign residents. This corresponded to what Nasiali describes as the shift in the use of vocabulary of local authorities and techniciens from 'asocial' or 'unadapted families' to an unvarnished description in terms of 'North African' and, especially, 'Algerian' families. Likewise, slums were less and less frequently referred to as 'slums' (îlots insalubres or taudis) but rather referred to as 'shantytowns' (bidonvilles), an ascription which took on both spatial and racialised characteristics.

This is not to say that these areas were not objects of attention for the French state, as we have seen. And such common sense understandings were fuelled by increased and often sensationalised media attention, as exemplified by the notorious June 1973 piece 'Suburbs of Fear' (Banlieues de peur) in Le Nouvel Observateur, describing the peripheries of Paris, Marseille and Toulouse as grim, barren and dangerous territories. But, complementing de Barros's analysis of Nanterre and Champigny's

\footnotetext{
33 Ibid., 113.

34 Ibid., 122-3.

35 On the harkis, including their experiences and memories of being corralled into housing in austere camps in rural France after Algerian independence, see Jeannette M. Miller, 'A Camp for Foreigners and “Aliens": The Harkis' Exile at the Rivesaltes Camp (1962-1964)', French Politics, Culture and Society, 31, 3 (2013), 21-44; Claire Eldridge, From Empire to Exile: History and Memory within the Pied-Noir and Harki Communities, 1962-2012 (Manchester: Manchester University Press, 2016).

36 Nasiali, Native to the Republic, 128.

37 Ibid., 91.
} 
bidonvilles, Nasiali's work suggests that, at the local level, social meanings were autonomous from the designs of detached government bureaucracies. In turn, this impacted on understandings of social citizenship. As we have seen, de Barros shows how a hermetic frontier was erected in the discourse of complaints about Paris bidonvilles, and that this was underpinned by fears of social downgrading (déclassement). Likewise, to see and physically be in the vicinity of urban areas held in disrepute was not simply an experience of repudiation or fear but also an affirmation of social hierarchy, indeed a sensorial justification for stratified access to social citizenship. The sight of 'asocial' 'gypsy' squatters or North Africans in shantytowns may have confirmed fears about immutable cultural and social differences. But by the same token their detracting onlookers found self-confirmation of their own supposed modernity. And it is striking that in written applications for housing, Marseille residents commonly expressed a desire to live a 'modern life' as a justification for prioritised access to new housing. Both de Barros and Nasiali thereby add a useful historicisation anchored in the double end of empire and the post-war boom to philosopher Jacques Rancière's analysis of urban divisions and how space at the sensorial level functions as a social metaphor. Worse than the underground of urban abjection would be its absence, and the corollary that there was no ground at all, that the social order was arbitrary, and differentiated prestige and social status correspondingly contingent or empty. $^{38}$

Another recent take on housing, and many other issues besides, is Félix Germain's Decolonizing the Republic: African and Caribbean Migrants in Postwar Paris, 1946-1974. Germain's contribution is to examine the growth of the African and Caribbean presence in Paris during the 'glorious thirty' (trente glorieuses), and with it the emergence of France's post-colonial black identities. Germain weaves between engaging discussions of black internationalism and student activism; African migration and its representations in documentaries; work, housing, colonial relations and the formation of oppositional identities among African workers; Caribbean women in post-war France; music and black identity and activism; the black community and French labour unions; and 'May '68 in Black'. A fundamental focus is the agency of black migrants as the primary agents of 'decolonization in the post-colonial period', which has been overshadowed by scholarly prioritisation of black intellectuals and prominent political figures. ${ }^{39}$

Much of the book focuses on housing and the home as forums for this work of decolonisation. The Parisian home was important to African and Caribbean students and workers in a double sense: both in and of itself given their concern for material comfort and security and also as a key forum in which they gathered to discuss and organise in view of their broader concerns as marginalised French citizens or immigrants and as anticolonial militants. Germain draws readers' attention to student accommodation, in an effort to rectify a tendency in the literature to overlook youth in discussions of the home. For Germain, student foyers were a quintessential site of 'colonial situations', the negotiation of which should be seen as an integral part of the decolonisation process. ${ }^{40}$ Germain notes the irony that the first foyers for colonial students had been created during the interwar period to control and suppress

\footnotetext{
38 See Jacques Rancière, 'Discovering New Worlds: Politics of Travel and Metaphors of Space', in George Robertson, Melinda Marsh, Lisa Tickner, Jon Bird, Barry Curtis and Tim Putnam, eds., Travellers' Tales: Narratives of Home and Displacement (London \& New York: Routledge, 1994), 33-4.

39 See, for example, Bennetta Jules-Rosette, Black Paris: The African Writers' Landscape (Chicago: University of Illinois Press, 1998); V.Y. Mudimbe, ed., The Surreptitious Speech: Présence Africaine and the Politics of Otherness, 1947-1987 (Chicago: University of Chicago Press, 1992); Gary Wilder, The French Imperial Nation-State: Negritude and Colonial Humanism Between the Two World Wars (Chicago \& London: University of Chicago Press, 2005); Wilder, Freedom Time: Negritude, Decolonization, and the Future of the World (Durham: Duke University Press, 2015). For a recent work which encompasses intellectuals, political figures, workers and students, see Michael Goebel, Anti-Imperial Metropolis: Interwar Paris and the Seeds of Third World Nationalism (New York: Cambridge University Press, 2015).

40 See Andrew M. Daily, 'Race, Citizenship, and Antillean Student Activism in Postwar France, 1946-1968', French Historical Studies, 37, 2 (2014), 331-57. See also the chapter 'Entirely Christian and Entirely African: African Students in Postwar France', in Elizabeth A. Foster, African Catholic: Decolonization and the Transformation of the Church (Cambridge, MA.: Harvard University Press, 2019), 124-51.
} 
their activities but by the post-war era had become breeding grounds for student activism. Again, the home was a site where the state's reach exceeded its grasp.

Germain points to the importance of private homes as a space for the organisation of political meetings, while foyers for African workers became 'sites of contestation and identity formation'. ${ }^{41}$ By the 1950s foyers designed to house the increasing number of migrant workers from Algeria and neighbouring European countries quickly became an integral part of the Parisian landscape. A decade later many foyers comprised of sub-Saharan African labour migrants sprouted up in the city. While certain French people accepted their new neighbours, others expressed discomfort and anger. A combination of inadequate conditions, poor value for money and constant supervision - usually by ex-colonial administrators - led to opposition among African residents. ${ }^{42}$ Germain makes the intriguing argument that the foyers generated oppositional sensibilities in a way that the workplace could not. Against the classic Marxist thesis of the class socialisation inherent to the factory, the individuating effects of work in post-war Paris were more liable to diminish the impetus to combat exploitation and colonial relations. By contrast, living together in the foyer generated a different dynamic, increasing self-confidence and fostering group unity and strength. As Germain puts it, the migrants felt more comfortable expressing their unwillingness to accept injustice and colonial treatment under their own roof, even if the foyer was understood to be merely a temporary home. ${ }^{43}$

Consequently, protests against the managers' behaviour and for better service became widespread throughout many African foyers in the Parisian region. Germain argues that 'by the late sixties, the protest for better housing had developed into a larger struggle against French hegemony over the private lives of African workers in Paris'. By this time these grievances had coalesced into a series of rent strikes, in response to which French administrators sided with the managers. ${ }^{44}$ Negotiations proceeded in the midst of tensions and quarrels, with police sending spies to the foyers and resorting to a divide and conquer strategy to defeat the demands for self-management that united various foyers. ${ }^{45}$

A further instructive case study pertaining to housing in Germain's study is his analysis of the experiences of Caribbean women in the French capital. Often stereotyped as jezebels or prostitutes, yet coveted as French citizens, they were considered variously as disruptive of domestic norms and as ideal candidates for domestic work. Migration of Caribbean women to the Paris area was organised from 1962 by the government agency 'The Office for Migration Management in the Overseas Departments' (Bureau pour le développement des migrations dans les départements d'outre mer; BUMIDOM), staffed in large part by ex-colonial administrators. Its objective was to direct Caribbean women towards low-skilled jobs and inculcate in them a higher French culture emphasising marriage and domesticity. For the most part, BUMIDOM officials guided these women towards domestic labour, claiming that the Parisian domestic industry was in crisis and that Caribbean women represented a perfect substitute for the Portuguese and Spanish women increasingly deserting these low-paid roles.

Despite all these valuable insights, Germain perhaps falls short in his primary goal of showing how African and Caribbean migrants decolonised the republic. This is a pity, since the verb 'decolonise' tends either to remain in the realm of abstract theorisation or to be overused in contemporary political discourse to the detriment of precision and analytical purchase. Fine-grained historical work tracing evolutions in explicit or implicit understandings of its meaning would, as such, be a boon to further historical scholarship. This is not to detract from the achievement of Germain's work in going beyond the scholarly focus on black intellectuals and politicians in France to offer an innovative and penetrating analysis of African and Caribbean workers' and students' activism in housing and in post-war Parisian life generally. However, to fully substantiate a claim for their successful decolonisation of

\footnotetext{
41 Ibid., 64.

42 Ibid., 66-7.

43 Ibid., 67.

44 Ibid., 68.

45 Ibid., 69-70.
} 
colonial hierarchies in housing, as well as in employment and social relations, further research is needed on such groups' interactions with broader social and political life in France. This would need to examine more closely how French institutions and non-black French interlocutors were led to rethink, challenge or dispense with colonial frames of reference in reaction to the agency of African and Caribbean claim making, which Germain so usefully highlights.

\section{$\bullet$}

Just months after Algerian independence in 1962 President de Gaulle pointed to the United Kingdom's failure to decolonise fully as proof of its lack of commitment to building Europe. It was a fundamental reason, the general averred, why the United Kingdom should be kept out of the burgeoning European community. In the same vein, in April 1963, one year after the Evian Accords that concluded the Algerian War, de Gaulle referred to French Algeria as part of a colonial project that had 'passed its expiration date. ${ }^{46}$ Such high-profile official pronouncements have engendered the perception of 1962, or the end of empire more broadly, as a stark threshold in French and European twentieth-century history, and as a fork in the road between empire and Europe. For their part, historians have been divided between those who see decolonisation as a meaningful temporal dividing line and those that stress the continuity of colonial practices and ideas into the post-colonial period, both in foreign affairs and in the treatment of immigrants in the European metropole.

To different degrees and in various ways, these five works come down on the side of foregrounding colonial continuities with crucial caveats that preclude any simplistic notion of 'bringing the empire home'. Rather, colonial ideas and practices were reworked and reactivated in different circumstances and according to different political and social parameters. These included renewed understandings of citizenship and shifting criteria for insiders and outsiders. Furthermore, colonial legacies were often neutralised, as when Algerians were subsumed into the category of 'immigrants', when colonial personnel took up positions back in the metropole without acknowledgement of the implications of their formative background or with the proffering of 'double racism' as a rationale for discriminatory housing policy.

Perhaps more useful than their answers to the question of the continuities and discontinuities of the post-colonial period, however, are two common approaches. These help us to rethink not only the home and housing but also many political and social issues in twentieth-century France. First, these works add to our understanding of the exercise and contradictions of power. Their focus on housing and the home add subtlety to our understanding of the scales, logics and multifaceted nature of French state administration. They also warn us against overly narrow pronouncements about the nature of the post-imperial French republic, since there was significant discrepancy in discourse and practice according to the various ways state power was configured. This was not only a question of the relationship between state and local government, or the calibration of technocracy, bureaucracy and personalised relations. It also involved how policy was mediated through engagement with external partners, notably charities, and through even seemingly innocuous daily, neighbourhood level interactions, which escaped the control and often the intentions of central power. The home and housing, then, allow us to glimpse both the ambitious reach of the French state and also the limitations of its grasp. In the same way, the multifaceted nature of the French state was both an asset and a limitation, extending its access even to domestic spaces but also sometimes seeing its plans disappointed on getting there. ${ }^{47}$

\footnotetext{
46 Shepard, The Invention of Decolonisation, 7.

47 On the question of the coherence of the rapidly growing post-war French state and the conditions for its relative successes in certain areas and failures in others, see Chapman, France's Long Reconstruction. Chapman's is particularly strong in his assessment of the post-war French state's reckoning with the heritage of the Third Republic and Vichy, post-1945 modernisation and colonial war in Indochina and Algeria, including the connections between these, whether readily perceived at the time or not. He is likewise attentive to how these governmental tensions and various horizons of policy impacted immigrants.
} 
Second, these works have much to say about French citizenship. Questions of security and belonging, affect and function, and the relation between material distribution and recognition all coalesced in the post-1945 French home. ${ }^{48}$ The home provides a case study of the contingency of apparently essential divisions between insiders and outsiders and the extent of their access to citizenship. To that end, the function of space as a metaphor for the social body in a way that eluded abstract ideas of remote government is a vital contribution. That such divisions between insiders and outsiders so commonly pivoted on a divide between European and non-European is also highly significant, since it indicates that scholars need to broaden their perspectives to understand the importance of discourses about Europe. If ideas of Europe and Europeanness informed the DG8 and of course inter-governmental and bureaucratic machinations in Brussels as a whole, this was also a vocabulary that underpinned access to housing and the standing of the home, even at the neighbourhood level. And it did so in multifarious and conflicting ways, at once promising inclusion while also maintaining control and hierarchy. Notions of modernisation and perceived Europeanness also had weighty implications for welfare provision and social citizenship. Yet, just as exclusion and inclusion were continuously in tension, clear demarcations between insiders and outsiders in the French republic were never steady or easily transferable across time and were often quite contingent on local contexts.

\footnotetext{
48 See Nancy Fraser \& Axel Honneth, Redistribution or Recognition?: A Political-Philosophical Exchange, trans. Joel Golb \& Christiane Wilke (London: Verso, 2003).
}

Cite this article: McDonnell H (2020). Bringing the French Empire (to the) Home? Contemporary European History 29, 356-368. https://doi.org/10.1017/S0960777320000302 